\title{
Study on Incentive Price of Fermented Cocoa to Overcome Reluctance of Farmers to Apply Fermentation: Case Study in Jembrana Regency
}

\author{
Djoko Soemarno $^{\left.1^{*}\right)}$, Yuli Haryati ${ }^{1)}$, Soetanto Abdoellah ${ }^{1)}$ and Diany Faila Sophia Hartatri ${ }^{1)}$ \\ ${ }^{1}$ Indonesian Coffee and Cocoa Research Institute, J1. PB. Sudirman 90, Jember Indonesia \\ ${ }^{*}$ Corresponding author: djokosoemarno@yahoo.co.id
}

\begin{abstract}
Improving cocoa quality through encouraging farmers to do fermentation is one of the ways to increase the added value of cocoa. However, majority of Indonesian farmers are reluctance to do fermentation. This research aimed to study factors causing farmers reluctant to do fermentation, weight difference between fermented and unfermented cocoa, cocoa processing time difference between fermented and unfermented cocoa, quality difference between fermented and unfermented coco refers to cocoa bean standard (SNI): 01-2323-2008/Amd-2010, and feasible added value incentive of fermented cocoa beans. The data collection were conducted through household farmers' survey, focus group discussion and experimental research. The experimental research was conducted to understand the weight and processing time differences; and to asess the quality, including moisture content, bean count, $\mathrm{pH}$ and fermentation index. Analysis of the data were conducted by methods of Fishbone Ishikawa and logit multiplier linear analysis. The research results showed that the main factors causing farmers reluctant to do fermentation were insuitable of selling price of fermented cocoa, the existence of village collectors in buying unfermented cocoa, the lack of cooperation among farmers in farmer group (Subak Abian) and the lack of farmers' skills on cocoa bean fermentation. This study also found that the weight depreciation difference between fermented and unfermented cocoa was $0.5-3.75 \%$, and the processing time difference between fermented and unfermented cocoa was 12-24 hours. Quality of fermented cocoa beans was higher than that of unfermented cocoa beans and it can fulfill the standard of SNI: 01-2323-2008/Amd-2010. It was found that the feasible added value incentive of fermented cocoa benas was 2,126-3,426 IDR/kg.
\end{abstract}

Keywords: cocoa, fermentation, unfermented, quality, incentive

\section{INTRODUCTION}

Cocoa is an important estate commodity which has significant contribution in the economy of Indonesia, producing export earnings, material for industry and creates job opportunity as well. According to Ditjenbun (2011) total acreage of cocoa estate in Indonesia is 1,650,621 ha spread in 32 provinces with production centers located in South Sulawesi, Central Sulawesi, South East
Sulawesi, and West Sulawesi. Most of the cocoa area $(92 \%)$ is managed by smallholders, $4 \%$ is managed by Government owned plantations, and $4 \%$ is managed by private estates. Since most of cocoa estates are managed by smallholderr, cocoa commodity can be used as medium for farmer development based on village. Therefore, beside having important contribution in national economy cocoa has also important contribution in smallholder economy (Aklimawati \& Ismayadi, 2015). 
Most of cocoa beans produced by smallholders classified is as low quality because it is unfermented. Therefore, Indonesian cocoa producers have low bargaining power in international market. Price of commodity including cocoa is influenced by several factors such as demand, supply, stock, exchange value of money, price of competitive commodity in the market (Marsh \& Mawardi, 2008), weather condition and global climate (Hendratno, 2010). Beside those factors the low cocoa price received by the farmer is also due to low quality of cocoa product. In a world market study, Dradjat (2002) showed that low quality had reduced competitiveness of main estate crop commodity of Indonesia.

One of the potential region for developing cocoa as superior commodity is Jembrana Regency in Bali. This region is one of the main producing cocoa in Bali Province with the area of 6,227 ha or $41.89 \%$ of the whole area in Bali (14,865 ha) (DPPK Jembrana, 2011). Most of the cocoa produced in Jembrana is managed by small holder farmers where their farming and processing system is traditional and simple. Some efforts have been conducted for supporting the farmers in Jembrana by improving the quality of cocoa with the target to increase their welfare. One of the effort is by supporting the farmers to apply cocoa fermentation. However in the application of fermentation programme many obstacles are found therefore most farmers produce unfermented. As the result cocoa price at the farmer level has not increased.

Up to now there has no study conducted on factors responsible for reluctance of farmers to produce fermented cocoa. The purpose of this researh are: 1) to reveal and identify factors which cause reluctance of farmers to do fermentation process for their cocoa beans; 2) to determine difference in weight between fermented and unfermented cocoa beans; 3 ) to determine different of time duration between fermented and unfermented processing of cocoa beans; 4) to determine quality of fermented and unfermented cocoa beans according to national quality standard of Indonesia (SNI) for the quality of cocoa beans i.e. 01-2323-2008/Amd 2010, and 5) to determine the most ideal price incentive for cocoa beans as added value.

\section{MATERIALS AND METHODS}

Research was conducted at Districts of Mendoyo and Melaya in Jembrana Regency, Bali. Primary and secondary data were used in the analysis. Primary data was obtained by survey on farmer household, experimental research, and focus group discussion (FGD). In the survey on farmer household 40 farmers were selected as respondents for cocoa farmers producing fermented cocoa as well as those who produced unfermented cocoa in the District of Mendoyo and Melaya, and the sampling of which was done by means of stratified random sampling.

Experimental research was done on four treatments. A treatment: the fresh cocoa beans were directly dried under sun until moisture content of $7.5 \%$. B treatment: the fresh cocoa beans were fermented during 5 days with once turning the beans at the third day, and then sun dried until moisture content of $7.5 \%$. C treatment: the fresh cocoa beans were stored in plastic bags during one night, then it was fermented during 5 days with once turning of the beans at the third day, and then sun dried until moisture content of $7.5 \%$. D treatment: the fresh cocoa beans were stored in plastic bags during two nights, then it was fermented during 5 days with once turning at the third day and then sun dried until moisture content of $7.5 \%$. 
For identifying constraints in fermentation experienced by the farmers data collection was done by means of FGD (Irwanto, 2006). Secondary data was collected from several institutions involved such as farmer group (Subak Abian), Badan Pusat Statistik (Statiistics Bureau), Dinas Perkebunan (Extension Service of Estate Crop), Indonesian Coffee and Cocoa Research Institute, and other supporting data.

Method of analysis for data collected by questionnaire were first by FishboneIshikawa (Ishikawa, 1985) analysis and second by Logit Regression analysis (Burgin, 2006). The first method was designed to analyse condition of deviation influenced by some reasons connected with reluctance of the farmers to apply cocoa fermentation. In the Logit Regression analysis the dependent variable $(Z)$ was qualitative data as nominal data in the form of dummy. Dummy in this dependent variable was farmers who want to do fermentation $(\mathrm{F})$ and farmers who reluctant to do fermentation (NF) with general model:

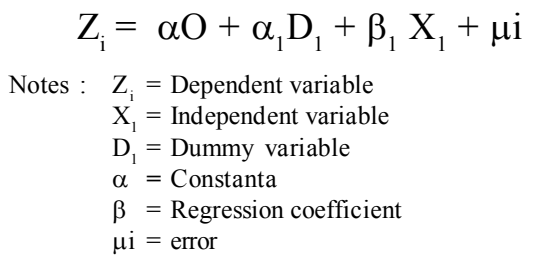

In this research there were 8 independent variables and dependent variables (Z) as dummy variables, so that the equation for Linear Probability Model was presented as follows:

$$
\begin{gathered}
\mathrm{Z}_{\mathrm{i}}=\alpha \mathrm{O}+\beta_{1} \mathrm{X}_{1}+\beta_{2} \mathrm{X}_{2}+\beta_{3} \mathrm{X}_{3}+\beta_{4} \mathrm{X}_{4}+ \\
\beta_{5} \mathrm{X}_{5}+\beta_{6} \mathrm{X}_{6}+\beta_{7} \mathrm{X}_{7}+\beta_{8} \mathrm{X}_{8}+\mathrm{D}
\end{gathered}
$$

Logit Model formula for

$P_{i}=E\left(\mathrm{Z}=1 / X_{i}\right)=\frac{1}{1+e^{-\mathrm{Zi}}}$ with $\mathrm{Z}_{\mathrm{i}}=\beta_{\mathrm{o}}+\beta_{1}$

$$
\begin{aligned}
\frac{\mathrm{P}_{\mathrm{i}}}{\left(1-\mathrm{P}_{\mathrm{i}}\right)}= & \begin{array}{l}
\text { odd ratio explained the chance } \\
\text { of farmers who had tendency } \\
\text { for not producing fermented } \\
\text { cocoa beans. }
\end{array}
\end{aligned}
$$

Notes:

$\mathrm{Z}_{\mathrm{i}}=$ Reluctance for doing fermentation of cocoa beans

$\mathrm{O}=$ Reluctant to do fermentation (NF)

$1=$ Want to do fermentation $(\mathrm{F})$

$\mathrm{X}_{1}=$ Inconformity sale price of cocoa beans at farmer level

$\mathrm{X}_{2}=$ Duration of time in applying fermentation method

$\mathrm{X}_{3}=$ Number of trader who go around to meet the farmer

$\mathrm{X}_{4}=$ Difficulty of the farmers to apply fermentation in the processing of cocoa beans

$\mathrm{X}_{5}=$ Supply of capital for the farmers to apply fermentation process

$\mathrm{X}_{6}=$ Solidity of the farmers in Subak Abian group

$\mathrm{X}_{7}=$ Vision of the farmers on the importance of fermentation of cocoa beans

$\mathrm{X}_{8}=$ Skill of the farmers to apply fermentation process of cocoa beans

$\mathrm{D}=$ Dummy variable for fermentation of cocoa beans

$\alpha=$ Constanta

$\beta=$ Regression coefficient

Methods of analysis for data obtained by using experiment was done by counting tabulated data obtained from treatment on processing since fermentation up to sun drying of cocoa beans to moisture content of $7.5 \%$. Parameters observed consisted of environmental temperature, decrease in weight every 6 hours and testing the quality of cocoa beans in the laboratory of ICCRI in Jember based on Indonesian National Standard for Cocoa Beans (SNI 01-23232008/Amd-2010) consisted of moisture content, bean count $(\mathrm{BC})$ analysis, $\mathrm{pH}$ and analysis on fermentation index (FI) (BSN, 2012).

\section{Added Value of Processing}

For determining conversion value and price of fermented cocoa beans based on data obtained from the experiment on cocoa processing in the field tabulation and analysis of added value was done. Added value was decrease of material cost plus other input from value of product, excluding cost of manpower, or added value was compensation for manpower and profit of fermented cocoa 
beans (Soeharjo, 1991). In this research, calculation was done started from input of cocoa beans material up to standard of dry cocoa beans according to the formula:

$$
\mathrm{NT}=\text { Output Value }- \text { Input }
$$

or

Added Value $=$ Labour Contribution $(\mathrm{LC})+$ Capital Contribution (CC)

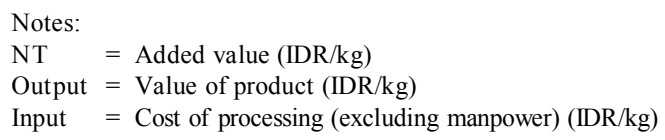

\section{RESULTS AND DISCUSSION}

In the world market, cocoa beans of Indonesia got price discount because the majority of Indonesian cocoa beans had a low quality (Baon, et al., 2005). It was reflected from very low fermentation index, dirt content, moulded beans, empty beans, and high content of impurities. These facts was responsible for decrease price of cocoa beans at the farmer level. To overcome the low price of cocoa beans suggestion has been given to farmers to produce fermented cocoa beans. Humphrey \& Schmitz (2002) mentioned that product upgrading, such as quality improvement the competitive power of product in the global market could increase. However the application of fermentation by small scale farmers was only sporadic and with various method, and therefore fermented cocoa beans done by the farmers has not yet been fit with the standard. In addition there was no appreciable price incentive for different quality (Misnawi \& Wahyudi, 2008).

The farmers in Jembrana Regency had limited access to knowledge and market information including price difference between fermented and unfermented cocoa beans. Therefore, the perception of the farmers was no price difference between fermented and unfermented cocoa beans.

\section{Responsible Factors}

Quality and price of cocoa beans at the farmer level was influenced by market and existence of trader in the farmer level. If the farmer applied fermentation of their cocoa beans there was opportunity for increased price of their cocoa beans. However, many farmers were reluctant to do fermentation due to some factors. In the analysis to study the factors responsible for reluctance of farmers, FGD was conducted with local cocoa farmers. Based on the results of FGD the factors responsible were 1) unagreeable sale price of cocoa beans at the farmer level, 2) additional time needed for cocoa processing, 3) many collecting traders who bought unfermented cocoa beans, 4) fermentation process was sophisticated for being done by the farmers, 5 ) limited capital of the farmers, and this factor influenced money circulation, 6) less solidity within farmer group (Subak Abian), 7) limited knowledge of the farmers on fermentation process, and 8) limited skill of the farmers to apply fermentation of cocoa beans.

The result of FGD on factors responsible for the reluctance of the farmer to do fermentation of their cocoa beans analyzed by regression analysis was presented in Table 1.

Based on result of statistical (Table 1) test, significant value of $\mathrm{X}_{1}$ was lower than $\alpha=0.10(0.076<0.10)$, so that unagreeable sale price of fermented cocoa beans at the farmer level significantly influenced reluctance of farmer to do fermentation. Value of regression coefficient of $\mathrm{X}_{1}$ factor was minus 1.995 and value of Exp. (B) was $0.136\left(\mathrm{e}^{1.995}\right)$ which showed that the more 
Table 1. Results of logistic regression analysis of variables X1-X8 To Z

\begin{tabular}{lccccc}
\hline Variables & B & S.E. & Wald & Sig. & Exp. (B) \\
\hline X1 & -1.995 & 1.125 & 3.143 & $0.076 *$ & 0.136 \\
X2 & -0.692 & 1.429 & 0.234 & 0.628 & 0.501 \\
X3 & 2.304 & 1.315 & 3.068 & $0.08 *$ & 10.014 \\
X4 & 1.112 & 1.033 & 1.158 & 0.282 & 3.039 \\
X5 & 0.875 & 1.199 & 0.533 & 0.465 & 2.398 \\
X6 & 2.868 & 1.579 & 3.301 & $0.069 *$ & 17.6 \\
X7 & 1.448 & 0.914 & 2.509 & 0.113 & 4.253 \\
X8 & 4.642 & 2.312 & 4.032 & $0.045 *$ & 10.375 \\
Constant & -28.706 & 14.638 & 3.846 & 0.05 & 0 \\
\hline
\end{tabular}

Notes: $\left.{ }^{*}\right)=$ Significant at $90 \% ; \mathrm{X}_{1}=$ Inconformity sale price of cocoa beans at farmer level, $\mathrm{X}_{2}=$ Duration of time in applying fermentation method, $X_{3}=$ Number of trader who go around to meet the farmer, $X_{4}=$ Difficulty of the farmers to apply fermentation in the processing of cocoa beans, $\mathrm{X}_{5}=$ Supply of capital for the farmers to apply fermentation process, $\mathrm{X}_{6}=$ Solidity of the farmers in Subak Abian group, $\mathrm{X}_{7}=$ Vision of the farmers on the importance of fermentation of cocoa beans, $\mathrm{X}_{8}=$ Skill of the farmers to apply fermentation process of cocoa beans.

unagreeable sale price of fermented cocoa beans received by the farmer they were more reluctant to do fermentation.

Significant value of $\mathrm{X}_{2}$ was higher than $\alpha=0.10(0.628<0.10)$ which showed that duration of cocoa beans processing by means of fermentation method $\left(\mathrm{X}_{2}\right)$ did not significantly influenced on reluctance of farmers to apply fermentation of cocoa beans. Value of regression coefficient of $\mathrm{X}_{2}$ factor was minus 0.692 and value of Exp. (B) was $0.501\left(\mathrm{e}^{0.692}\right)$ which meant that the longer duration of time for conducting fermentation process, the farmer preferred to sell their cocoa beans as unfermented cocoa beans.

The value of $\mathrm{X}_{3}$ was lower than tolerated error, i.e. $\alpha=0.10(0.80>0.10)$ which meant that the factor of number of traders who bought unfermented cocoa beans at the farmer level did not significantly cause reluctance of the farmers to produce fermented cocoa beans. The presence of traders therefore did not influence interest of farmer to produce fermented cocoa. Value of regression coefficient of $\mathrm{X}_{3}$ factor was 2.304 and value of Exp. (B) was 10.014 $\left(\mathrm{e}^{2.304}\right)$ which meant that the more percep- tion of the farmer that many of the traders around wouldlike to buy unfermented cocoa beans, and the farmer preferred not to apply fermentation.

Based on result of testing, the significant value of $\mathrm{X}_{4}$ was higher than $\alpha=0.10$ $(0.282>0.10)$ which meant that difficulty factor for conducting fermentation process did not significantly influence on the reluctance of the farmers to conduct fermentation of cocoa beans. Value of regression coefficient of $\mathrm{X}_{4}$ factor was 1.112 and value of Exp. (B) was 3.039 ( $\left.\mathrm{e}^{1.112}\right)$ which meant that the more perception of the farmer that fermentation process was complicated or difficult the farmer preferred to apply fermentation process. In other words the fermentation process was not complicated.

Aklimawati \& Ismayadi (2015) mentioned that supply of capital for the farmers seems to influence technology of production adopted by the farmers. However, in adopting technology of cocoa processing it appeared that supply of capital did not influence the interest of farmer to conduct fermentation. It was presented in the research result that significant value of $\mathrm{X}_{5}$ was higher than $\alpha=0.10(0.465>0.10)$ which meant 
that the supply of capital for the farmers to apply fermentation did not significantly influence reluctance of the farmers to apply fermentation. Value of regression coefficient of $\mathrm{X}_{5}$ factor was 0.875 and value of Exp. (B) was $2.398\left(\mathrm{e}^{0.875}\right)$ which meant that the higher the capital supply for the farmer to apply fermentation, it would like to increase opportunity to apply fermentation as much as 2.4 times, with assumption that other variables were constant. In other words the higher the capital supply for doing fermentation process, the higher the preference of the farmer to apply fermentation of their cocoa beans.

Based on research result the significant value of $\mathrm{X}_{6}$ was lower than tolerated error, i.e. $\alpha=0.10(0.069<0.10)$ which meant that solidity of the farmers in Subak Abian significantly influenced reluctance of the farmer to apply fermentation of cocoa beans. Value of regression coefficient of $\mathrm{X}_{6}$ factor was 2.868 and value of Exp. (B) was 17.6 $\left(\mathrm{e}^{2.868}\right)$ which meant that the more solid the farmer in Subak Abian it wouldlike to increase opportunity to apply fermentation by 17.6 times under the assumption that other variables remained constant. Strengthtening farmer institution was therefore needed in order to improve the quality of their cocoa beans. In the case of Arabica coffee, efforts to improve coffee quality in several regions such as Kintamani, Bali; Flores, East Nusa Tenggara, and Bondowoso, East Java the programme of Mediated Patnership Model (MOTRAMED) had been executed at the farmer group. Hartatri (2015) mentioned that execution of MOTRAMED had been succeded in improving quality and price of coffee at the farmer level. Therefore quality improvement via application of MOTRAMED in the cocoa farmer group is expected to increase their interest to practice fermentation of cocoa beans.
Subak Abian was established based on the Tri Hita Kirana phylosophy, the elements of which consisted of Parahyangan (communication with God), Pawongan (communication between people) and Palemahan (communication with surrounding environment) (SAAN, 1986). Pawongan is expressed in the form of paruman (routine meeting of Subak Abian) and working together (gotong royong). Routine meeting and working together in Jembrana Regency generally also cover agricultural activity, including agronomy and processing of cocoa (Hartatri, 2014). Besides, paruman is an access for the farmer to have information linked with cocoa production aspects. Therefore, if Subak Abian become more solid and intensive in supplying information and stimulate the farmers to do fermentation then improvement of cocoa quality through fermentation can be increased.

Based on the research result the significant value of $X_{7}$ was higher than $\alpha=0.10$ $(0.113>0.10)$ which meant that the farmer vision factor did not significantly influence on reluctance of cocoa farmers to apply fermentation of cocoa beans. Value of regression coefficient for $\mathrm{X}_{7}$ factor was 1.448 and value of Exp. (B) was $4.253\left(\mathrm{e}^{1.448}\right)$ which meant that increase of vision of the farmer on the importance of fermentation could increase possibility of the farmer to apply fermentation by 4.3 times, under the assumption that other variables were constant. In other words the higher the vision of the farmer on the importance of fermentation of cocoa beans, the farmer were more enthusiastic to apply fermentation. Results of this analysis showed that access of the farmer to extension and training activities on aspects of cocoa production had an influence on processing system at the farmer level. Hartatri (2015) mentioned that due to intervention of the government through extension service and assistance via the programme of MOTRAMED 
in Arabica coffee at Kintamani (Bali) it had increased access of farmers to knowledge on quality of product and market information, and increased application of wet method of coffee processing. As a result quality of coffee has been improved and the price of coffee at the farmer level increased.

Significant value of $\mathrm{X}_{8}$ was lower than $\alpha=0.10$ which meant that factor of farmer skill in the application of cocoa beans fermentation significantly influenced reluctance of farmerr to do fermentation of their cocoa beans. Value of regression coefficient of $\mathrm{X}_{8}$ was 4.642 and value of Exp. (B) was 10.375 $\left(\mathrm{e}^{4.642}\right)$ which meant that increase of farmer skill to apply fermentation process of cocoa beans could increase opportunity of the farmers to do fermentation as much as 10.4 times under assumption that other variables were constant. In other words the higher the farmer skill in doing fermentation process, the farmer preference to apply fermentation was also increased. Facilitating extention service and training for the farmer in Kintamani (Bali) their skill in applying wet processing of coffee beans increased (Hartatri, 2015).

\section{Bean Weight and Time Issues}

Based on results of observation presented in Table 2, it appeared that total weight reduction in A treatment was less than that of other treatments because the cocoa beans was directly sun dried without fermentation process. In B treatment cocoa beans was directly fermented and afterwards they were sun dried. Weight reduction in $\mathrm{C}$ and $\mathrm{D}$ treatments were relative high because the cocoa beans was preserved during one night and two nights respectively, then fermented and afterwards sun dried.

However based on results of the experiment there was no significant difference regarding duration of time needed to produce fermented and unfermented cocoa beans. Therefore it would not significantly influenced on money circulation in the farmer household. However based on observation in the field most of the farmer did not dried their cocoa beans up to moisture content of $7.5 \%$, the reason of which was to accelerate money rotation for the sake of household need such as food and education. There was indication that cocoa commodity had relative important influence on strategy of farmer earnings in Jembrana.

\section{Cocoa Beans Quality}

In general quality of cocoa beans can be seen physically or based on their flavour. Physical quality consisted of moisture content, existence of live insect, smoke odour, foreign matters, broken beans, mouldy beans, unfermented beans (slaty beans), dirt content and bean count. Flavour quality could be test based on sensory test such as aroma, sweetness, astringent, bitterness, earthy, mouldy, smoky, hammy etc.

Table 2. Effects of fermentation treatment on weight change of cocoa beans and time needed

\begin{tabular}{|c|c|c|c|c|c|c|}
\hline Treatment & $\begin{array}{c}\text { Wet weight } \\
(\mathrm{kg})\end{array}$ & $\begin{array}{l}\text { Dry weight } \\
(\mathrm{kg})\end{array}$ & $\begin{array}{l}\text { Weight decrease } \\
\qquad(\mathrm{kg})\end{array}$ & $\begin{array}{l}\text { Weight decrease } \\
\text { compared to } \\
\text { treatment A } \\
(\mathrm{kg})\end{array}$ & $\begin{array}{l}\text { Weight decrease } \\
\text { compared to } \\
\text { treatment A } \\
(\%)\end{array}$ & $\begin{array}{c}\text { Timed needs, } \\
\text { hours }\end{array}$ \\
\hline A & 40 & 15.00 & 25.00 & - & - & 216 \\
\hline B & 40 & 13.50 & 26.50 & 1.5 & 3.75 & 228 \\
\hline $\mathrm{C}$ & 40 & 14.40 & 25.60 & 0.6 & 1.5 & 246 \\
\hline D & 40 & 14.80 & 25.20 & 0.2 & 0.5 & 246 \\
\hline
\end{tabular}


At the farmer level like in coffee comodity, Robusta as well as Arabica price decision by local traders in Indonesia is generally only based on physical quality of beans, especially moisture content. Flavour test is only done at the exporter level or cocoa processing industry. It is especially caused by limited knowledge on flavour quality, skill and instrument owned by the traders to do flavour test. Besides, limited capital of traders at the village level was also responsible for omission of flavour test in cocoa by local traders.

Based on result of quality test presented in Table 3 it appeared that high percentage of slaty bean was found in A treatment, i.e. $46.5 \%$. The high number of slaty beans in this treatment was caused by direct sun drying of fresh cocoa beans without fermentaton process. In $\mathrm{B}, \mathrm{C}$, and $\mathrm{D}$ treatments, average percentage of slaty beans was maximum $3 \%$. Referring to quality standard in SNI 01-23232008/Amd-2010, cocoa beans of B, C, and $D$ treatments fulfilled qualification for the first quality with maximum $3 \%$ slaty beans. On the other hand, product of A treatment with $46.5 \%$ slaty beans according to SNI for cocoa beans was not included in quality class, so in the international market it was classified as low quality, and so it influenced the price of cocoa beans produced by the farmers. Results of analysis for other parameters showed no mouldy beans, germinated beans and beans with insect in all of the treatments. Waste content of all treatment was low, varying between $0.75-1.25 \%$, while standard of quality was maximum $1.5 \%$ for first quality, $2 \%$ for second quality and $3 \%$ for third quality.

Moisture content is one of the important physical quality and is most considered by buyer because beside its effect on recovery of dry beans it also has much influence on resistance of cocoa beans to damage especially during storage and transportation. In the condition of high moisture content, cocoa bean is very sensitive to mould and insect infestation. Based on observation in the field in order to reach moisture content of $7.5 \%$ A treatment required 9 days of sun drying for cocoa beans, whereas $\mathrm{B}$ treatment required 4-5 days, $C$ and $D$ treatments required 4 days sun drying (Table 4). Fermentation process therefore could accelerate sun drying process of cocoa beans.

Other physical quality of cocoa beans which often be used as reference in determining price is $\mathrm{pH}$ value. Measurement of $\mathrm{pH}$ of cocoa beans is generally not done at the level of collecting trader and big trader because of limited or absence of instrument.

Table 3. Effect on fermentation treatments on physical quality of cocoa beans

\begin{tabular}{|c|c|c|c|c|c|c|}
\hline \multirow{2}{*}{ Treatment } & \multirow{2}{*}{ Test } & Mouldy beans & Slaty beans & Insected beans & Sprouted beans & Waste \\
\hline & & \multicolumn{5}{|c|}{$\%$} \\
\hline \multirow[t]{3}{*}{$\mathrm{A}$} & 1 & 0 & 47 & 0 & 0 & 1.00 \\
\hline & 2 & 0 & 46 & 0 & 0 & 1.50 \\
\hline & Average & 0 & 46.5 & 0 & 0 & 1.25 \\
\hline \multirow[t]{3}{*}{ B } & 1 & 0 & 2 & 0 & 0 & 1.00 \\
\hline & 2 & 0 & 4 & 0 & 0 & 1.00 \\
\hline & Average & 0 & 3 & 0 & 0 & 1.00 \\
\hline \multirow[t]{3}{*}{$\mathrm{C}$} & 1 & 0 & 2 & 0 & 0 & 1.00 \\
\hline & 2 & 0 & 2 & 0 & 0 & 0.50 \\
\hline & Average & 0 & 2 & 0 & 0 & 0.75 \\
\hline \multirow[t]{3}{*}{$\mathrm{D}$} & 1 & 0 & 1 & 0 & 0 & 1.00 \\
\hline & 2 & 0 & 0 & 0 & 0 & 1.00 \\
\hline & Average & 0 & 0.5 & 0 & 0 & 1.00 \\
\hline
\end{tabular}


Table 4. Effects of fermentation treatments on moisture content, $\mathrm{pH}$, bean count, and fermentation index

\begin{tabular}{|c|c|c|c|c|c|}
\hline Treatment & Test & $\begin{array}{l}\text { Moisture contents } \\
(\%)\end{array}$ & $\mathrm{pH}$ & Bean count & $\begin{array}{c}\text { Fermentation } \\
\text { index }\end{array}$ \\
\hline \multirow[t]{3}{*}{ A } & 1 & 7.59 & 6.21 & 97 & 0.378 \\
\hline & 2 & 7.27 & 6.22 & 98 & 0.379 \\
\hline & Average & 7.43 & 6.22 & 98 & 0.379 \\
\hline \multirow[t]{3}{*}{ B } & 1 & 7.08 & 5.55 & 94 & 0.971 \\
\hline & 2 & 7.43 & 5.62 & 104 & 0.968 \\
\hline & Average & 7.25 & 5.59 & 99 & 0.970 \\
\hline \multirow[t]{3}{*}{$\mathrm{C}$} & 1 & 7.50 & 5.52 & 98 & 1.118 \\
\hline & 2 & 7.23 & 5.48 & 102 & 1.115 \\
\hline & Average & 7.36 & 5.50 & 100 & 1.116 \\
\hline \multirow[t]{3}{*}{$\mathrm{D}$} & 1 & 7.42 & 5.44 & 95 & 1.206 \\
\hline & 2 & 7.33 & 5.45 & 99 & 1.210 \\
\hline & Average & 7.38 & 5.45 & 97 & 1.208 \\
\hline
\end{tabular}

Like in the case of flavour quality, $\mathrm{pH}$ measurement is generally done by exporter. According to SNI good quality of cocoa beans is cocoa beans with $\mathrm{pH}$ value about 5.5. Based on the result of $\mathrm{pH}$ testing (Table 4) A treatment showed the highest $\mathrm{pH}$ value, i.e. 6.22 while for $\mathrm{B}, \mathrm{C}$, and $\mathrm{D}$ treatments $\mathrm{pH}$ was $5.45-5.59$. Therefore, B, C and $\mathrm{D}$ treatments produced high quality cocoa beans according to SNI.

Physical quality of cocoa beans is also related to size of the beans. Bean size of cocoa is expressed as number of bean (bean count, BC) per $100 \mathrm{~g}$. The greater the bean size of cocoa the better the quality of the cocoa beans. Bean size of dry cocoa beans is much influenced by quality of plant material, field condition during fruit development (such as rainfall), agronomic system (maintenance of plant and fertilizer application) and post harvest implementation. Results of experiment showed that range of bean counts in all treatments were $98-100$, and there was no significant difference in $\mathrm{BC}$ between all of the treatment.

Fermentation process was perfect when fermentation index (FI) value was 1 (one). If it was less than 1 the fermentation process was not perfect or unfermented. On the other hand if the value of FI was more than 1 it meant that the cocoa beans was over fermented. Proper fermentation process had an important role in the formation of flavour of cocoa beans. Therefore, the value of FI was used as an indicator for price of cocoa. Analysis for detecting value of FI was executed using spectrophotometer at wavelength of $360 \mathrm{~nm}$ and $420 \mathrm{~nm}$.

Based on the results of analysis (Figure 1) $B$ treatment showed nearly perfect fermentation, i.e. 0.97. The FI values of $\mathrm{C}$ and $\mathrm{D}$ were more than 1 which indicated over fermentation since in both treatment the process of cocoa beans fermentation was done inside plastic bag during 1 and 2 nights respectively. In A treatment the value of FI was 0.3787 which showed that there was no fermentation.

\section{Added Value Price}

Based on data presented in Table 5 the price of cocoa beans of A treatment after reaching standard dry beans was IDR18.667,during experiment. After being calculated with cost of manpower and instrument cost the corrected price was IDR19.602,- and 


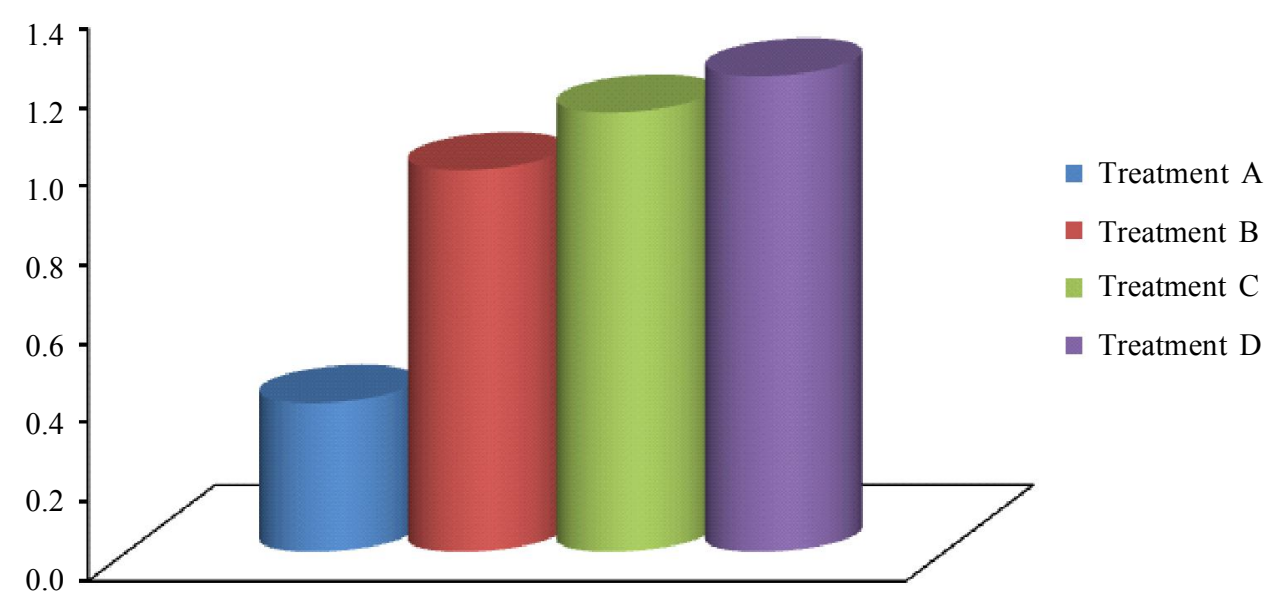

Figure 1. Effects of fermentation treatments on fermentation index of cocoa bean produced

Table 5. Conversion and incentive value price fermented cocoa beans

\begin{tabular}{|c|c|c|c|c|}
\hline \multirow[t]{2}{*}{ Treatment } & Price cocoa & Conversion value & $\begin{array}{l}\text { Price difference with } \\
\text { conversion value }\end{array}$ & $\begin{array}{c}\text { Value difference } \\
\text { conversion compared with } \\
\text { treatment A }\end{array}$ \\
\hline & \multicolumn{4}{|c|}{ IDR } \\
\hline A & 18.667 & 19.602 & 935 & - \\
\hline B & 20.741 & 21.728 & 987 & $2.126,-$ \\
\hline $\mathrm{C}$ & 21.878 & 22.943 & 1.065 & $3.341,-$ \\
\hline $\mathrm{D}$ & 21.963 & 23.028 & 1.065 & $3.426,-$ \\
\hline
\end{tabular}

difference between both price was IDR935,in each $\mathrm{kg}$ of cocoa beans. The cocoa beans of A treatment was original cocoa beans without fermentation that generally was produced by most of the farmer in Jembrana Regency. Differences due to calculation of manpower and instrument cost were between IDR935 to IDR1.065 for each $\mathrm{kg}$ of cocoa beans.

Based on conversion values of cocoa beans price pattern (Figure 2) it would be profitable for the farmers if they applied D treatment in their business, because of the greater added value compared to other treatments. However from the interest of traders, it would be profitable if they bought cocoa beans produced by A treatment because the chance to get added value was better compared to that of other treatments.
Comparing A treatment (representative of original cocoa beans) and other treatments which applied fermentation method, Table 5 presented added value incentives IDR2.126,for B treatment, IDR3.341,-- for C treatment and IDR3.426,- for D treatment. It was obvious that the ideal price of fermented cocoa beans for the farmer who applied fermentation method was IDR2.126,-- to IDR3.426,per $\mathrm{kg}$ of dry cocoa beans. If the buyer wouldlike to give premium price to the farmer who applied fermentation the price might be higher. The magnitude of incentive value was ideal for the farmers to compensate for their efforts in managing cocoa and to appreciate their willingness to improve the quality of cocoa beans in relation to the development of domestic cocoa industry. Besides there 


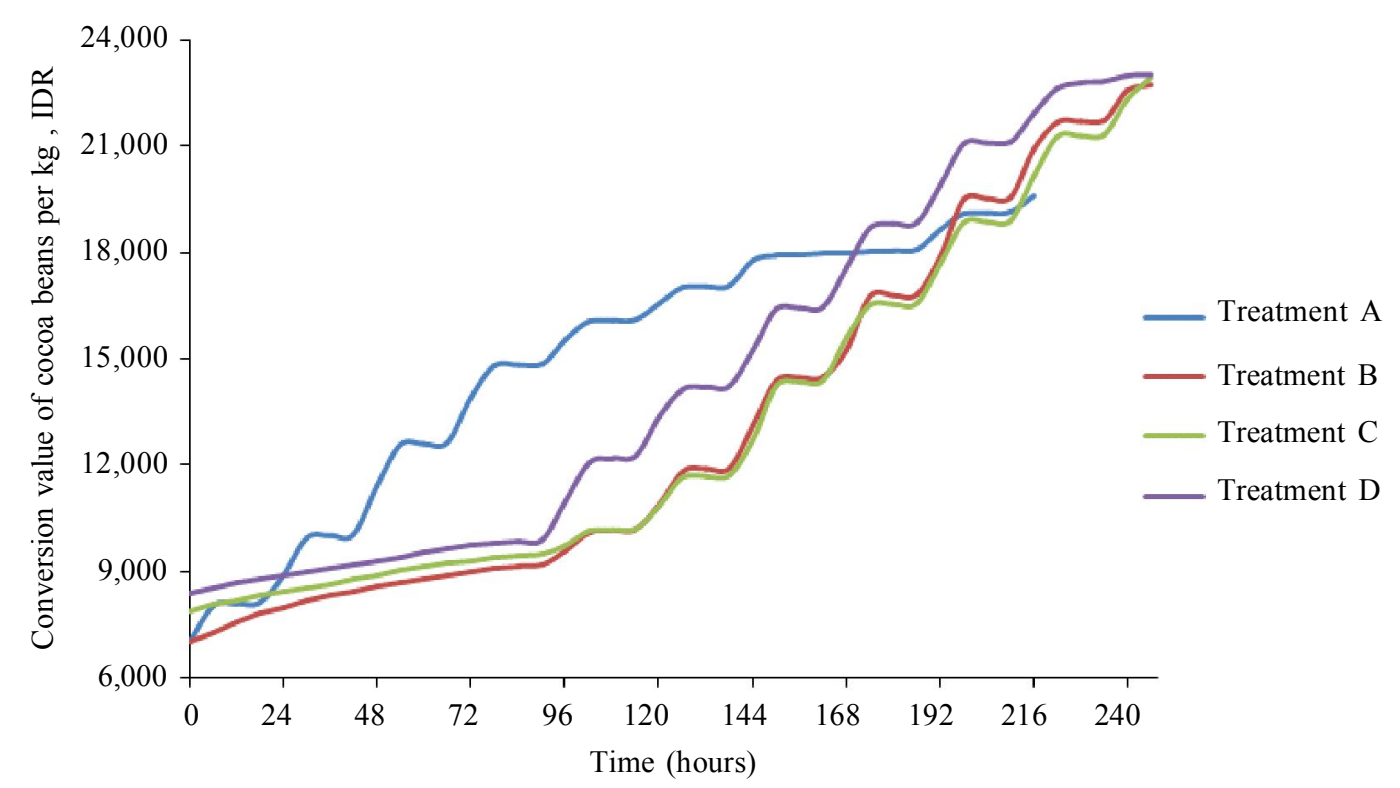

Figure 2. Relationship between conversion value (IDR/kg) and time (hours) needed for fermentation of cocoa beans

was experience which could be noted that farmers as well as local traders realized that fermentation of cocoa beans was suitable for being applied by the farmers to obtain better price.

The cocoa farmers in Jembrana Regency is recommended to apply fermentation of their cocoa beans, either individually or together in the group, because it improves the quality of product and added economic value of cocoa beans. For supporting its success, local government is expected to strengthen the programme of quality improvement and marketing of cocoa beans at the farmer level. The buyers or local traders have to make more condusive and directed relation with Subak Abian in partnership programme involving local government and ICCRI as mediator.

\section{CONCLUSION}

The main factor which caused reluctance of the farmer in Jembrana Regency to apply fermentation of cocoa beans was unmatched selling price of fermented cocoa beans, solidity of farmers in the group of Subak Abian and skill of farmers in applying fermentation of cocoa beans. There was difference in reduced weight as much as $0.5-3.75 \%$ between fermented and unfermented cocoa beans. There was difference in duration of processing of cocoa beans during 12-24 hours or $0.5-1$ day between fermented and unfermented cocoa beans. Fermented cocoa beans produced better quality characteristics and fulfilled National Standard of Indonesia for cocoa beans (SNI 01-2323-2008/Amd2010) while the unfermented cocoa beans did not match with the qualification. The farmer who applied fermentation process of their cocoa beans should be given price incentive by means of added value as much as IDR2.126 to IDR3.426,- per $\mathrm{kg}$ of cocoa beans.

\section{ACKNOWLEDGEMENT}

The first author would like to thank DG of Higher Education, Ministry of National Education for providing Superior Fellowship 
Program; to Director of ICCRI for further studty permission; and Jembrana Agriculture, Plantation and Maritim Service for supporting field work.

\section{REFFERENCES}

Aklimawati, L. \& C. Ismayadi (2015). Ekonomi kakao: Aspek Produksi. pp. 654-682. In: Kakao: Sejarah, Botani, Proses Produksi, Pengolahan dan Perdagangan. T. Wahyudi, Pujiyanto \& Misnawi (Eds.). Gadjah Mada University Press. Yogyakarta.

Baon, J.B.; Herman \& A. Purwoto (2005). Prospek dan Arah Pengembangan Agribisnis Kakao. Badan Penelitian dan Pengembangan Pertanian. Jakarta.

BSN (2012). SNI Biji Kakao. Standar Nasional Indonesia. SNI 01-2305-2008/Amd 2010. Badan Standardisasi Nasional. Jakarta.

Bungin, B. (2006). Metodologi Penelitian Kuantitatif. Kencana Prenada Media Group. Jakarta.

DPPK Jembrana (2011) Perkembangan Luas Areal, Produksi, Produktivitas, Jumlah Petani dan Tenaga Kerja Perkebunan Rakyat Tahun 2010. Dinas Pertanian, Perkebunan dan Kelautan Kabupaten Jembrana Propinsi Bali. Negara, Bali.

Ditjenbun (2011). Statistik Perkebunan Indonesia 2008-2010, Kakao. Direktorat Jenderal Perkebunan. Kementerian Pertanian. Jakarta.

Dradjat, B. (2002). Prospek ekspor produk perkebunan: implikasi strategis bagi Indonesia. Seminar Penerapan Otonomi Daerah dan Daya Saing Agribisnis Perkebunan. Lembaga Riset Perkebunan Indonesia, Bandung, 26-27 Juni, 2002.
Hartatri, D.F.S. (2014). Kondisi sosial dan ekonomi petani kopi Arabika di lokasi MOTRAMED: Studi kasus di Kintamani. Warta Pusat Penelitian Kopi dan Kakao Indonesia, 26, 38-43.

Hartatri, D.F.S (2015). Indonesia value chain structures and smallholders' livelihoods: A case study of specialty coffee development interventions. Masters Tesis. Sydney University.

Hendratno, S. (2010). Pengaruh anomali iklim terhadap harga karet alam. Warta Perkaretan, 29, 50-54.

Humphrey, J. \& H. Schmitz (2002). How does insertion in global value chains affect upgrading in industrial clusters? Regional Studies, 36, 1017-1027.

Irwanto (2006) Focus Group Discussion (FGD): Sebuah Pengantar Praktis. Yayasan Obor Indonesia. Jakarta.

Ishikawa, K. (1985). Pengendalian Mutu Terpadu (Terjemahan). CV. Remaja Maju. Bandung.

Misnawi \& T. Wahyudi (2008). Peranan Mutu dalam Daya Saing dan Peluang Pasar Komoditas Kakao. Makalah Teknologi Pasca Panen. Pusat Penelitian Kopi dan Kakao Indonesia. Jember.

Soeharjo, A. (1991). Profil Agroindustri. Kumpulan Makalah Penataran Dosen Perguruan Tinggi Swasta Bidang Pertanian Program Kajian Agribisnis. Direktorat Jenderal Pendidikan Tinggi. Jakarta.

SAAN (1986). Awig-Awig Subak Abian Amertha Nadi. Subak Abian Amertha Nadi, Kabupaten Daerah Tingkat II Jembrana. Negara, Bali.

$$
* * 0 * *
$$

